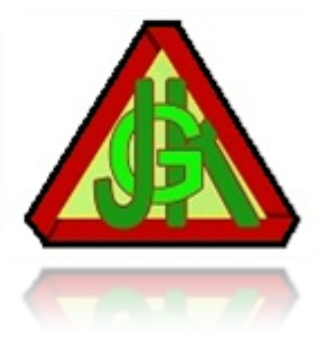

\title{
PENGARUH TERAPI OKUPASI AKTIVITAS WAKTU LUANG (MENYAPU, MEMBERSIHKAN TEMPAT TIDUR, MENANAM TANAMAN DAN MENGGAMBAR) TERHADAP GEJALA HALUSINASI PENDENGARAN
}

\author{
Rif'ah Fauziah Mustopa ${ }^{1}$, Asih Minarningtyas $^{2}$, Aty Nurillawaty ${ }^{3}$ \\ 1,2,3 Jurusan Keperawatan D-3/STIKes Bani Saleh \\ Bekasi, Indonesia \\ e-mail : fauziyahriri829@gmail.com ${ }^{1}$, vyzkhalishah@yahoo.com ${ }^{2}$, \\ atyrahayu43@gmail.com ${ }^{3}$
}

\begin{abstract}
Abstrak
Prevalensi gangguan jiwa berat seperti skizofrenia mencapai sekitar 400.000 orang atau sebanyak 1,7 per 1.000 penduduk.Halusinsi yang paling banyak terjadi adalah halusinasi pendengaran, sekitar $70 \%$ penderita mengalami halusinasi pendengaran, $20 \%$ halusinasipenglihatan, dan $10 \%$ adalah halusinasi penciuman, pengecapan danperabaan. Salah satu penanganan pasien halusinasi adalah dengan terapi okupasi. Terapi okupasi ialah cara atau bentuk psikoterapi suportif sangat penting untuk meningkatkan pemulihan pasien. Terapi okupasi membantu merangsang pasien melalui aktivitas yang disukai. Salah satu jenis terapi okupasi yaitu diindikasikan untuk pasien yang berhalusinasi adalah aktivitas waktu luang seperti menyapu, membersihkan tempat tidur. Tujuan penulisan literature review ini agar mengetahui pengaruh terapi okupasi terhadap gejala pada pasien halusinasi pendengaran berdasarkan penelusuran literature review. Desain dalam Karya Tulis Ilmiah ini adalah literature riview dengan menggunakan metode pencarian electronic data base dan sumber pencarian google schoolar. Dari penulisan ini ditemukan 3 artikel di google schoolar yang membahas tentang pengaruh terapi okupasi aktivitas waktu luang berdasarkan klasifikasi dan outcome yangsesuai dengan kriteria penelitian. Hasil literatre riview dari ketiga artikel menunjukkan bahwa terapi okupasi aktivitas waktu luang berpengaruh terhadap perubahan gejala pada pasien halusinasi pendengaran. Berdasarkan hasil tersebut, maka terapi okupasi aktivitas dapat diterapkan pada pasien dengan halusinasi pendengaran untuk menurunkan gejalanya.
\end{abstract}

Kata Kunci: halusinasi pendengaran, penurunan gejala halusinasi, terapi okupasi aktivitas waktu luang

\footnotetext{
Abstract

The prevalence of severe mental disorders such as schizophrenia reaches about 400,000 people or as much as 1.7 per 1,000 population. The most common hallucinations are auditory hallucinations, about $70 \%$ of patients experience auditory hallucinations, $20 \%$ visual hallucinations, and $10 \%$ are olfactory, tasting
} 
and tactile hallucinations. One of the treatments for hallucinatory patients is occupational therapy. Occupational therapy is a very important way or form of supportive psychotherapy to improve patient recovery. Occupational therapy helps stimulate the patient through activities he enjoys. One type of occupational therapy that is indicated for patients who hallucinate is free time activities such as sweeping, cleaning the bed. The purpose of writing this literature review was to determine the effect of occupational therapy on symptoms in patients with auditory hallucinations based on a literature review search. The design in this scientific paper was a literature review using an electronic database search method and a google schoolar search source. From this writing, found 3 articles on Google Schoolar that discussed the effect of occupational therapy on leisure activities based on classification and outcomes in accordance with the research criteria. The results of the literature review of the three articles show that occupational therapy for leisure activities has an effect on changes in symptoms in patients with auditory hallucinations. Based on these results, occupational activity therapy can be applied to patients with auditory hallucinations to reduce their symptoms.

Keywords: auditory hallucinations, decreased symptoms of hallucinations, leisure activities occupational therapy

\section{PENDAHULUAN}

Gangguan jiwa merupakan perilaku yang muncul karena kelainan yang bukan dari perkembangan norma manusia. Biasanya penyakit jiwa menyerang pikiran seseorang, yang bisa menyerang seluruh bagian tubuh. Seseorang yang mengalami gangguan jiwa biasanya akan mengalami kesulitan tidur, rasa tidak nyaman dan berbagai gangguan lainnya. Gangguan jiwa adalah cara berpikir (kognitif), kemauan (kemauan), emosi (afektif), tindakan (psikomotor) ${ }^{(1)}$.

Data WHO (2016), terdapat sekitar 35 juta penderita depresi, 60 juta penderita bipolar, 21 juta penderita skizofrenia, dan 47,5 juta penderita demensia. Di Indonesia dengan berbagai faktor psikologis, psikologis dan sosial dengan jumlah penduduk yang beragma, kemudian jumlah kasus gangguan jiwa terus meningkat yang berdampak pada peningkatan beban negara dan produktivitas manusia dalam jangka panjang. Data Riskesdas 2018 menunjukkan prevalensi gangguan jiwa emosional yang bercirikan gejala gejala pada penduduk usia 15 tahun ke atas mencapai 6,1\% dari total penduduk Indonesia. Sedangkan prevalensi gangguan jiwa berat seperti skizofrenia mencapai sekitar 400.000 orang atau 
sebanyak 1,7 per 1.000 penduduk. Gangguan mental adalah masalah serius dan harus diselesaikan perhatian karena tingginya jumlah penderita, angka prevalensi yang paling tinggi adalah mengalami gangguan jiwa dengan diagnosis halusinasi (2).

Dampak gangguan jiwa yang serius terhadap keluarga cukup kompleks. Berbagai faktor berkontribusi terhadap kompleksitas ini termasuk kurangnya informasi tentang diagnosis penyakit oleh penyedia layanan kesehatan, reaksi keluarga terhadap diagnosis pasien, berkurangnya interaksi antara keluarga dan pasien, dan strategi koping keluarga yang tidak efektif yang mempengaruhi tingkat gejala dan peningkatan kekambuhan ${ }^{(3)}$.

Berbagai faktor juga dapat mempengaruhi nilai sosial dan budaya dalam masyarakat yang mengalami gangguan jiwa seperti faktor globalisasi dan kemajuan pesat teknologi informasi. Tidak semua orang memiliki kemampuan untuk itu menyesuaikan dengan berbagai perubahan. Jika individu tidak dapat melakukan koping adaptif maka individu bisa mengalami risiko gangguan $\operatorname{kejiwaan}^{(4)}$.

Penelitian terapi okupasi aktivitas waktu luang terhadap perubahan gejala halusinasi pendengaran pada pasien skizofrenia dengan hasil $\mathrm{p}=0,000$ yang berati ada pengaruh terapi okupasi aktivias waktu luang terhadap gejala halusinasi pendengaran pada pasien skizofrenia ${ }^{(5)}$.

Berdasarkan penelitian lainnya tentang terapi okupasi berpengaruh pada perubahan gejala halusinasi, diberikan terapi okupasi karena pada saat melaksanakan terapi okupasi dapat meminimalkan interaksi pasien dengan dunianya sendiri, mengeluarkan pikiran, perasaan atau emosi yang telah mempengaruhi perilaku yang tidak didasarkan padanya ${ }^{(6)}$.

\section{METODE}

Metode dalam penulisan karya ilmiah ini menggunakan studi literature riview, studi literature riview adalah uraian tentang teori, temuan dan baha penelitian lain yang di peroleh dari bahan acuan untuk dijadikan landasan kegiatan penelitian untuk menyusun kerangka pemikiran yang jelas dari permusuhan 
masalah yang ingin di teliti. desain dalam Karya Tulis Ilmiah ini adalah literature riview dengan menggunakan metode pencarian electronic data base dan sumber pencarian google schoolar formulasipencarian literature sebagaiberikut :

$\mathrm{P}:$ Pasienhalusinasi pendengaran

I :terapi okupasi

$\mathrm{C}:-$

$\mathrm{O}$ :perubahan gejala

$\mathrm{T}: 2011-2021$

Berdasarkan formulasi PICO diatas, maka penulis merumuskan research question yaitu: adakah pengaruh terapi okupasi aktivitas waktu luang terhadap perubahan gejala pada pasien halusinasi pendengaran ?"

Literatur review dilakukan dengan mencari publikasi artikel ilmiah dari literatur pendidikan kesehatan dan medis, pencarian dilakukan menggunakan database: Google Scholar, Pubmed, Semantic Scholar pencarian literatur menggunakan keyword:

1. Google Scholar menggunakan keyword : Pasien halusinasi pendengaran DAN terapi okupasi DAN perubahan gejala DAN Quasy-experiment

2. PudMed menggunakan keyword : auditory hallucinations AND occupational therapy AND changes in symptoms Quasy-Experiment

3. Semantic scholar menggunakan keyword : Pasien halusinasi pendengaran DAN terapi okupasi DAN perubahan gejala DAN Quasy-experiment.

\section{HASIL DAN PEMBAHASAN}

\section{Hasil}

Hasil penelitian pertama menunjukkan bahwa pemberian terapi okupasi aktivitas waktu luang dapat menurunkan gejala halusinasi pendengaran pada pasien skizofrenia sebelum diberikan pre test sebanyak 12 orang dalam kategori sedang. Setelah diberika post test terapi okupasi aktivitas waktu luang terbanyak12 orang $(60,00 \%)$ berada dalam kategori ringan ${ }^{(5)} \cdot$ Maka dapat ditarik kesimpulan terapi okupasi aktivitas waktu luang dpat menurunkan gejala halusinasi. 
Hasil penelitian kedua menunjukan sebagian besar gejala halusinasi pendengaran pada klien halusinasi pendengaran setelah diberikan terapi okupasi paling banyak dalam kategori ringan dengan jumlah responden 12 responden dengan persentase $44,4 \%$. Dapat disimpulan bahwa terjadi penurunan gejala halusinasi pendengaran setelah diberikan erapi okupasi karena pada saat pelaksanaan terapi okupasi dapat meminimalisasi interaksi pasien dengan dunianya sendiri.

Hasil penelitian ketiga menunjukkan total seluruh responden penelitian ditemukan ada 3 responden yang gejala halusinasinya meningkat sebelum dan setelah diberikan terapi okupasi aktivitas waktu luang. Dari total 15 responden terdapat 3 yang meningkat (20\%) dan 12 responden menurun $(80 \%)$. Berdasarkan hasil penelitian yang dilakukan, maka dapat ditarik kesimpulan yaitu, ada pengaruh yang signifikan pemberian terapi okupasi aktivitas waktu luang terhadap perubahan gejala halusinasi.

Hasil penelitian menunjukkan sebelum diberikan terapi okupasi aktivitas menggambar terbanyak dalam kategori sedang taitu 15 orang (50\%). Setelah diberikan terapi okupasi aktivitas menggambar terbanyak dalam kategori ringan yaitu 21 orang $(70 \%)^{(8)}$.. Ini menunjukkan bahwa terapi okupasi aktivitas menggambar dapat menurunkan gejala halusinasi pendengaran.

\section{Pembahasan}

Gejala halusinasi pendengaran yang dialami pasien skizofrenia sebelum diberikan (pre-test) terapi okupasi aktivitas waktu luang terbanyak 12 orang $(60,00 \%)$ berada dalam kategori sedang. Gejala halusinasi pendengaran yang dialami pasien skizofrenia setelah diberikan (pos-test) terapi okupasi aktivitas waktu luang terbanyak 12 orang $(60,00 \%)$ berada dalam kategori ringan. Hasil penelitian menunjukan ada pengaruh yang sangat signifikan pemberian terapi okupasi aktivitas waktu luang terhadap perubahan gejala halusinasi pendengaran yang dialami oleh pasien skizofrenia $(p=0,000<p=0,010)$. Pada penelitian pemberian terapi okupasi aktivitas waktu luang yang dilakukan adalah kegiatan menyapu dan merapikan tempat tidur dapat menurunkan gejala halusinasi 
pendengaran pada pasien skizofrenia. Hasil penelitian ini menunjukkan bahwa pemberian terapi okupasi aktivitas waktu luang dapat menurunkan gejala halusinasi pendengaran pada pasien skizofrenia diberbagai tatanan pelayanan kesehatan yang $\operatorname{ada}^{(5)}$.

Hasil penelitian keduamenunjukan sebagian besar gejala halusinasi pendengaran pada klien halusinasi pendengaran setelah diberikan terapi okupasi paling banyak dalam kategori ringan dengan jumlah responden 12 responden dengan persentase $44,4 \%$. Terjadi penurunan gejala halusinasi pendengaran setelah diberikan terapi okupasi karena pada saat pelaksanaan terapi okupasi dapat meminimalisasi interaksi pasien dengan dunianya sendiri, mengeluarkan pikiran, perasaan, atau emosi yang selama ini mempengaruhi perilaku yang tidak disadarinya, memberi motivasi dan memberikan kegembiraan, hiburan, serta mengalihkan perhatian pasien dari halusinasi yang dialami sehingga pikiran pasien tidak terfokus dengan halusinasinya khusus nya pada pasien halusinasi pendengaran. Aktivitas waktu luang yang dilakukan seperti menanam sayuran ${ }^{(7)}$.

Hasil penelitian ketiga yang dilakukan 15 responden terdapat perubahan yang sangat signifikan dari total 15 responden terdapat 3 yang meningkat $(20 \%)$ dan 12 respondn yang menurun (80\%), maka dapat ditarik kesimpulan yaitu, ada pengaruh pemberian terapi okupasi aktivitas waktu luang terhadap perubahan gejala halusinasi. Aktivitas waktu luang yang diberikan dalam hal ini adalah kegiatan aktivitas sehari-hari berupa aktivitas menyapu, mengepel, melipat pakaian dan membersihkan tempat tidur Yyang sangat bermanfaat bagi lingkungan sekitar dan bagi penderita itu sendiri ${ }^{(10)}$.

Berdasarkan hasil penelitian keempat yang dilakukan 30 responden, sebelum diberikan terapi okupasi aktivitas waktu luang menggambar terbanyak dalam kategori sedang yaitu 15 orang (50\%).setelah diberikan terapi okupasi terbanyak dalam kategori ringan yaitu 21 orang (70\%). Aktivitas waktu luang yang dilakukan yaitu menggambar. Maka dapat ditarik kesimpulan yaitu, ada pengaruh pemberian terapi okupasi aktivitas waktu luang terhadap perubahan gejala halusinasi ${ }^{(8)}$. 
Tabel 1. Sebelum dan Sesudah Diberikan Terapi Okupasi

\begin{tabular}{lll}
\hline No & \multicolumn{1}{c}{ Sebelum } & \multicolumn{1}{c}{ Sesudah } \\
\hline 1. & 12 orang kategori sedang $(60 \%)$ & 12 orang kategori ringan $(60 \%)$ \\
\hline 2. & 14 orang kategori sedang $(51,9 \%)$ & 12 orang kategori ringan $(44,4 \%)$ \\
\hline 3. & 15 orang kategori sedang & 12 orang kategori ringan $(80 \%)$ \\
\hline 4. & 15 orang kategori sedang $(50 \%)$ & 21 orang kategori ringan $(70 \%)$ \\
\hline
\end{tabular}

Jika dilihat dari segi waktu berdasarkan keempat artikel ini, yang berjudul Terapi okupasi aktivitas waktu luang terhadap perubahan gejala halusinasi pendengaran. Membutuhkan waktu satu bulan yaitu bulan Mei-Juni $2013^{(5)}$. Berbeda dengan terapi yang dilakukan selama 2 minggu dengan 1 minggu dilakukan 3 sesi pertemuan, sehingga terdapat 6 sesi pertemuan untuk 2 minggu ${ }^{(7)}$. Penelitian ketiga dilakukan 1 bulan mulai 19 November-19 Desember $2015^{(10)}$. Sedangkan penelitian keempat, waktu untuk melakukan tiap aktivitas menggambar adalah 45 menit, dilakukan 1-2 kali sehari selama ${ }^{(8)}$.

Jika dilihat dari perubahan gejala halusinasi, penelitian pertama menunjukan setelah dilakukan terapi okupasi aktivitas waktu luang pada 20 responden yaitu 12 orang $(60 \%)$ dalam kategori ringan ${ }^{(5)}$. Penelitian kedua mendapatkan hasil 27 responden menunjukan setelah diberikan terapi okupasi paling banyak dalam kategori ringan dengan jumlah responden 12 responden dengan persentase $44,4 \%{ }^{(7)}$. Penelitian ketiga mendapatkan hasil 15 responden ditemukan ada 3 responden (20\%) yang gejala halusinasinya meningkat sebelum dan sesudah dilakukan terapi okupasi aktivitas waktu luang dan 12 responden $(80 \%)$ mengalami penurunan ${ }^{(10)}$. Hasil penelitian keempat, dari 30 orang dengan jumlah 21 responden $(70 \%)$ dalam kategori ringan ${ }^{(8)}$. Dari ketiga jurnal ini hasil paling efektif yaitu penelitian ketiga.

Terapi okupasi merupakan salah satu bentuk psikoterapi suportif berupa aktivitas yang membangkitkan kemandirian secara manual, kreatif dan edukatif untuk beradaptasi dengan lingkungan dan meningkatkan derajat kesehatan fisik dan mental pasien serta makna hidup ${ }^{(9)}$. Tentang terapi okupasi berpengaruh pada perubahan gejala halusinasi, diberikan terapi okupasi karena pada saat melaksanakan terapi okupasi dapat meminimalkan interaksi pasien dengan 
dunianya sendiri, mengeluarkan pikiran perasaan atau emosi yang telah mempengaruhinya perilaku yang tidak didasarkan pada nya ${ }^{(6)}$.

Salah satu penanganan pasien halusinasi adalah dengan terapi okupasi ialah cara atau bentuk psikoterapi suportif sangat penting untuk meningka tkan pemulihn pasien. Terapi okupasi membantu merangsang pasien melalui aktivitas yang disukai. Salah satu jenis terapi okupasi yaitu diindikasikan untuk pasien yang berhalusinasi adalah aktivitas waktu luang. Kegiatan ini bertujuan untuk memberi motivasi dan memberikan kegembiraan hiburan, serta mengalihkan perhatian pasien halusinasi, sehingga pemikiran pasien tidak berfokus dengan halusinasinya ${ }^{(5)}$. Berdasarkan hasil penelitian yang telah dikumpulkan dan teori yang ada, peulis beropini bahwa terapi okupasi aktivitas waktu luang dengan kegiatan menyapu, membersihkan tempat tidur, menanam tanaman dan menggambar sangat efektif diterapkan untuk menurunkan gejala pada pasien dengan halusinasi pendengaran karena aktivitas ini dapat memberi rasa gembira sehingga pikiran asien dapat dialihkan.

\section{SIMPULAN}

Berdasarkan literature review dari 4 artikel yang telah dilakukan dengan menggunakan metode PICO dalam penerapan terapi okupasi menunjukkan bahwa terapi okupasi berpengaruh pada perubahan gejala pada pasien halusinasi pendengaran. Terapi okupasi aktivitas waktu luang yang dilakukan seperti menggambar, menyapu, merapihkan tempat tidur, dan menanam tanaman dilakukan sehari 1-2 kali dapat meminimalkan interaksi pasien dengan dunia nya sendiri dan dapat menurunkan gejala halusinasi. Untuk peneliti selanjutnya, sebaiknya peneliti memperhatikan gejala halusinasi yang di alami oleh pasien halusinasi pendengaran, dan menambah referensi terapi okupasi aktivitas waktu luang selain dengan menggambar, menyapu, merapikan tempat tidur dan menanam sayuran. 
Rif’ah Fauziah Mustopa, Asih Minarningtyas, Aty Nurillawaty. Juni 2021. 14

(1): 40-49

\section{UCAPAN TERIMA KASIH}

Ucapan terima kasih kepada pembimbing satu dan pembimbing dua yang telah membantu dan memberi pengarahan dalam menyelesaikan literature review ini.

\section{DAFTAR RUJUKAN}

1. Kementerian Kesehatan Republik Indonesia. InfoDatin-Kesehatan-Jiwa. 2019. Jakarta

2. Maulana I, S S, Sriati A, Sutini T, Widianti E, Rafiah I, et al. Penyuluhan Kesehatan Jiwa untuk Meningkatkan Pengetahuan Masyarakat tentang Masalah Kesehatan Jiwa di Lingkungan Sekitarnya. Media Karya Kesehat. 2019;2(2):218-25.

3. Mashudi S, Nasriati R, Octaviani E. Terapi Okupasi Sebagai Sarana Peningkatan Kesehatan Jiwa Penderita Skizofrenia. J Abdidas. 2020;1(5):313-7.

4. Jatinandya MPA. Terapi Okupasi Pada Pasien Dengan Halusinasi Di Rumah Sakit Umum Daerah Banyumas. J Keperawatan Muhammadiyah Sept 2020. 2020;(September):295-301.

5. Wijayanti, N.M, Candra, I.W, Ruspawan I. Terapi okupasi aktivitas waktu luang terhadap perubahan gejala halusinasi pendengaran pada pasien skizofrenia. J Gema Keperawatan. 2010;7 No.1:1-7.

6. Halusinasi G, Rsj DI, Soerodjo P, Saptarani N, Erawati E, Sugiarto A. Studi Kasus Aktivitas Menggambar Dalam Mengontrol. 2020;3(1).

7. Fitri NY. Pengaruh Terapi Okupasi terhadap Gejala Halusinasi Pendengaran Pada Pasien Halusinasi Pendengaran Rawat Inap di Yayasan Aulia Rahma Kemiling Bandar Lampung. J Kesehat Panca Bhakti Lampung. 2019;7(1):33.

8. Candra IW, Rikayanti NK. Perubahan Halusinasi Pada Pasien Skizofrenia. J Gema Keperawatan. 2011;(2010):1-7.

9. Kaharingan E, Bidjuni H, Karundeng M. Pengaruh Penerapan Terapi Okupasi Terhadap Kebermaknaan Hidup Pada Lansia Di Panti Werdha 
Rif'ah Fauziah Mustopa, Asih Minarningtyas, Aty Nurillawaty. Juni 2021. 14 (1): $40-49$

Damai Ranomuut Manado. J Keperawatan UNSRAT. 2015;3(2):107312.

10. Hidayat J. Pengaruh Terapi Okupasi Aktivitas Waktu Luang Terhadap Perubahan Gejala Halusinasi pada Pasien. 2021;(January). 